\title{
Dehydration curve, gas exchange, and nutritional value of Bermudagrass hay under different conditions of storage
}

\section{Curva de desidratação, trocas gasosas e valor nutricional do feno capim Bermuda sob diferentes condições de armazenamento}

\author{
Ivaldir William Junior Machado ${ }^{1}$; Marcela Abbado Neres²; Deise Dalazen \\ Castagnara ${ }^{3}$; Caroline Daiane $\mathrm{Nath}^{4}$; Tatiana Garcia Diaz ${ }^{4}$
}

\begin{abstract}
The aim of this study was to characterize the dehydration curve and, gas exchange of bermudagrass (Cynodon dactylon L.) as well as the nutritional value of hay under different conditions of storage. The dehydration curve was evaluated at 7 time point $(0,13,18,22,37,42$, and 44 hours after cutting) until baling, using five replicates. The time 0 (zero) corresponded to the time before cutting, performed at 19:00 hours. The design was completely randomized with measures repeated over time. Gas exchanges was evaluated 0,14 , and 18 hours after cutting, using 10 replicates. The nutritional value of cowpea hay was evaluated in two open and closed environments (SO and CS), three storage times (30, 60, and 90 days), and five replications. Dehydration of hay was carried out for 44 hours, rapid rates of dehydration was observed in the leaves. Gas exchange was more intense before cutting and up to 14 hours after cutting. Crude protein (CP) content was higher at the time of cutting and decrease after storage. The in vitro dry matter digestibility (IVDMD) and neutral detergent fiber (NDF) content showed no variation between the sampling time and storage systems evaluated. Bermudagrass hay presents rapid dehydration and undergoes changes in the bromatological composition with storage time. Internal temperature of the hay bale did not exceed the ambient temperature.
\end{abstract}

Key words: Cynodon. Digestibility. Forage conservation. Photosynthesis.

\section{Resumo}

O objetivo deste estudo foi caracterizar a curva de desidratação, as trocas gasosas do capim Bermuda (Cynodon dactylon L.) e o valor nutritivo do feno sob diferentes condições de armazenamento. A curva de desidratação foi avaliada durante 7 horários $(0,13,18,22,37,42$ e 44 horas após o corte) até o enfardamento, com cinco réplicas. O tempo 0 (zero) correspondeu ao tempo antes do corte, realizado à19:00 horas (tempo 0). O delineamento foi inteiramente casualizado com medidas repetidas no tempo. As trocas gasosas foram avaliadas nos tempos 0,14 e 18 horas após o corte, utilizando 10 repetições. $\mathrm{O}$ valor nutricional do feno de do capim- bermuda foi avaliado em dois ambientes, aberto e fechado (SO e CS), três tempos de armazenamento (30, 60 e 90 dias) e cinco repetições. Observou-se que a desidratação do capim Bermuda ocorreu em 44 horas, com taxas rápidas de desidratação nas folhas.

1 M.e, Zootecnia, Universidade Estadual do Oeste do Paraná, UNIOESTE, Marechal Cândido Rondon, PR, Brasil. E-mail: wj_ machado1@hotmail.com

2 Prof ${ }^{a}$ Dra , Departamento de Zootecnia, UNIOESTE, Marechal Cândido Rondon, PR, Brasil. E-mail: mabaneres@gmail.com

3 Prof ${ }^{\text {a }}{ }^{\text {a }}$, Departamento de Medicina Veterinária, Universidade Federal do Pampa, UNIPAMPA, Uruguaiana, Rio Grande do Sul, Brasil. E-mail: deisecastagnara@yahoo.com.br

4 Discentes, Pós-Doutorado em Zootecnia, Programa de Pós-Graduação em Zootecnia, UNIOESTE, Marechal Cândido Rondon, PR, Brasil. E-mail: karolynedayane@hotmail.com; tatianagarcia.diaz@gmail.com

* Author for correspondence 
As trocas gasosas foram mais intensas antes do corte e até 14 horas após o corte. Os teores de proteína bruta (PB) foram maiores no momento do corte, diminuindo após o armazenamento. Os teores de digestibilidade in vitro da matéria seca (DIVMS) e fibra em detergente neutro (FDN) não apresentaram variação nos períodos e sistemas de armazenamento avaliados. O feno do capim Bermuda apresenta desidratação rápida e sofre alterações na composição bromatológica com tempo de armazenamento. A temperatura interna do fardo não excedeu a temperatura ambiente.

Palavras-chave: Cynodon. Digestibilidade. Conservação forrageira. Fotossíntese.

\section{Introduction}

The use of conserved forage has been relegated in Brazil since there have been no extreme weather conditions for several years. This change of use was initiate by horse breeders, who are currently the most important buyers, thereby leading to a change in the use of conserved forage in Brazil.

According to Neres et al. (2017), commercialization of hay has grown due to the ease of transportation, availability of machinery in the market and more affordable price. The basic principle of haymaking can be summarized as conservation of the nutritional value of forage by rapid dehydration, thereby curbing the respiratory activity of plants and microorganisms. Quick dehydration can maintain the quality of the forage, resulting in hay with good nutritional value (CALIXTO JÚNIOR et al., 2007).

The genus Cynodon is considered one of the most important grasses, and with Tifton 85 (Cynodon spp.) being the most commonly used. This cultivar was developed by Dr. Glen Burton in 1943 (BURTON et al., 1993) in the Coastal Plain Experiment Station (USDA - University of Georgia) in Tifton, Southern Georgia State, by crossing a South African introduction (PI 290884) with Tifton 68 grass. However, there are also other representatives of the Bermudagrass within this genus (Cynodon dactylon L.), such as "Pyramid", "Mirage" and "CD 90160", that have been developed through various improvements, which despite having already been studied in the United States, were only recently introduced in Brazil. However, few studies have been carried out with Bermudagrass under Brazilian conditions, especially with respect to hay production. The present trial was carried out in order to study the dehydration curve and gas exchange of Bermudagrass and to determine the nutritional value of hay under different conditions of storage.

\section{Materials and Methods}

\section{Experimental site, design, and treatments}

The trial was carried out on a farm that produces hay in Marechal Cândido Rondon, Paraná, with a total production area of 8 hectares. The local climate, classified according to Köppen, is of type Cfa, subtropical, with hot summers and rain well distributed throughout the year. The experimental area was classified as Oxisol/ Eutroferric Red Latosol (EMBRAPA, 2006) and had the chemical characteristics described below (Table 1).

Table 1. Chemical characteristics of the experimental area.

\begin{tabular}{ccccccccccccccc}
\hline \multirow{2}{*}{$\begin{array}{c}\mathrm{pH} \\
\text { water }\end{array}$} & \multicolumn{1}{c}{$\mathrm{mg} \mathrm{dm}^{-1}$} & \multicolumn{4}{c}{$\mathrm{cmolc} \mathrm{dm}^{-3}$} & \multicolumn{3}{c}{$\mathrm{V}$} & $\mathrm{MO}$ & \multicolumn{3}{c}{$\mathrm{mg} \mathrm{dm}^{-3}$} \\
\hline 5.5 & 24.45 & 0.91 & 6.29 & 2.1 & 0.0 & 3.59 & 9.3 & 12.89 & 72.15 & 23.24 & 20.05 & 9.4 & 158.0 & 30.7 \\
\hline
\end{tabular}

P: phosphorus (Mehlch); K: potassium (Mehlch); Ca: calcium (KCl 1 mol L-1); $\mathrm{Mg}$ : magnesium (KCl 1 mol L-1); Al: aluminum $\left(\mathrm{KCl} 1 \mathrm{~mol} \mathrm{~L}^{-1}\right)$; $\mathrm{H}+\mathrm{Al}$ : potential acidity (calcium acetate $0.5 \mathrm{~mol} \mathrm{~L}^{-1}$ ); SB: sum of bases; CEC: cation exchange capacity; V: base saturation; OM, organic matter (Boyocus Method); $\mathrm{Cu}$, copper; Zn, zinc; Mn, manganese; Fe, iron. 
The Bermudagrass area was introduced two years ago, and it was used exclusively to produce hay. Only biofertilizers, originating from a swine breeding farm and previously treated at a Canadian digester, were used in the area. Field fertilization to produce hay occurred 30 days before the cutting time for haymaking with $70 \mathrm{~m}^{3} \mathrm{ha}^{-1}$ biofertilizers used. The analysis of the biofertilizer showed the following results: $\mathrm{N}$ (flame AAS method, Kjeldahl): $0.10 \mathrm{~g} \mathrm{~kg}^{-1}, \mathrm{P}: 2.98 \mathrm{mg} \mathrm{kg}{ }^{-1}, \mathrm{~K}: 1.19 \mathrm{mg} \mathrm{kg}{ }^{-1}, \mathrm{Ca}:$ $0.28 \mathrm{mg} \mathrm{kg}^{-1}, \mathrm{Mg}: 0.05 \mathrm{mg} \mathrm{kg}^{-1}, \mathrm{Cu}: 0.15 \mathrm{mg} \mathrm{kg}^{-1}, \mathrm{Fe}$ : $1.34 \mathrm{mg} \mathrm{kg}^{-1}$, Mn: $0.25 \mathrm{mg} \mathrm{kg}^{-1}$ and Zn: $0.65 \mathrm{mg} \mathrm{kg}^{-1}$. Nitric-perchloric digestion (AOAC, 1990) was used for the determination of other nutrients. Readings take with an atomic absorption spectrophotometer (EAA) in flame mode (WELZ; SPERLING, 1999).

The forage was evaluated a for dry matter (DM) production and its structural characteristics. The DM production was determined using a $0.25 \mathrm{~m}^{2}$ metal box, which was thrown randomly into four different parts of the plot with $5 \times 30 \mathrm{~m}$ dimensions. The samples were packed in paper bags and subjected to forced ventilation oven at $55^{\circ} \mathrm{C}$ for 72 hours. In order to obtain the stem diameter, 20 tillers were sampled, and the stem diameter was measured before the first node with a caliper rule. Thereafter, the number of leaves per tiller was determined based on 20 tillers and the number of leaves was counted in each tiller of the plant. To determine the leaf/stem ratio, $50 \mathrm{~g}$ of the sample was taken and the parts (blade and stem + sheath) were manually separated, with subsequent drying under forced ventilation at $55^{\circ} \mathrm{C}$ for 72 hours. The leaf/stem ratio (L/S) was calculated by dividing the dry weight of leaves by the dry weight of stems.

The grass cutting was performed on November $10^{\text {th }}, 2012$, when the Bermudagrass was at 40 days of age since the start of regrowth, using a mower conditioner with free swinging flail fingers, with a cutting height of $5 \mathrm{~cm}$ from the soil. At the time cutting period, the production was $5,034.20 \mathrm{~kg} \mathrm{ha}^{-1}$ and the average stem diameter was $0.64 \mathrm{~mm}$. The tillers had 8.95 living leaves and 2.24 dead leaves, with an average of 11.19 leaves per tiller, whereas the mean leaf/stem ratio was 0.74 . The piles height was $12 \mathrm{~cm}$, as both temperature and rainfall had been favorable for forage growth.

After cutting, the forage remained piled in the field for 44 hours for, dehydration in order to reach the best DM contents for baling (above $800 \mathrm{~g} \mathrm{~kg}^{-}$ $\left.{ }^{1}\right)$. The weather conditions were favorable during this period, with a maximum temperature of $32.5^{\circ} \mathrm{C}$ on the day of baling. During dehydration, the piles were turned on the second day after cutting with a mechanic rake at 09.00 hours, after the dew had evaporated.

The dehydration curve was determined based on whole plant samples collected from the field. In the laboratory, the material (50 g) was separated into blade and stem + sheath with seven replications. Time 0 corresponds to the sample taken before cutting, carried out at 19.00 hours, whereas on other days, sampling was done, at 08.00, 13.00, and 17.00 hours. The analyzed parameters were evaluated 0 , $13,18,22,37,42$, and 44 hours (baling time) after the cutting time. Subsequently, the leaves and stems were dried in an oven with forced ventilation and kept at $55^{\circ} \mathrm{C}$ for 72 hours. After forage baling, each bale, with an average weight of $12 \mathrm{~kg}$, was stored in two places: one in open shed (OS) and the other in closed shed (CS) for 90 days.

\section{Gas exchange}

In order to analyze gas exchange during dehydration Bermudagrass, evaluations were carried out on the upper middle third of each stem of both developed and non-senescent leaves that were, fully expanded at, 0, 14 and 19 hours after cutting.

Gas exchange evaluations were performed using an infrared gas analyzer (IRGA, Li Model 6400XT inc. Lincoln, NE, USA). The $\mathrm{CO}_{2}$ concentration of the environment, ranging from 380 to $400 \mu \mathrm{mol}$ $\mathrm{CO}_{2} \mathrm{~mol}^{-1}$, was used as a reference during the evaluations. The following variables were analyzed: 
photosynthesis $\left(P n-{ }_{\mu} \mathrm{mol} \mathrm{CO} \mathrm{CO}^{-2} \mathrm{~s}^{-1}\right)$, transpiration

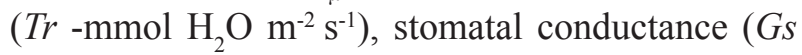
$-\mathrm{mol} \mathrm{m}^{-2} \mathrm{~s}^{-1}$ ), water use efficiency (WUE - ${ }_{\mu} \mathrm{mol} \mathrm{CO} \mathrm{CO}_{2}$ $\mathrm{m}^{-2} \mathrm{~s}^{-1} / \mathrm{mmol} \mathrm{H}_{2} \mathrm{O} \mathrm{m}^{-2} \mathrm{~s}^{-1}$ ), and leaf respiration ( $L R$ ${ }_{\mu} \mathrm{mol} \mathrm{CO}_{2} \mathrm{~m}^{-2} \mathrm{~s}^{-1}$ ). In each of the experimental units, expanded leaves were chosen, and readings were taken from the middle part of the leaf according to Pasqualotto et al. (2015).

\section{Analytical procedures}

To determine the bromatological composition of hay, approximately, $300 \mathrm{~g}$ samples were collected at each studied time point: before cutting, 30, 60, and 90 days after baling and storage in both OS and CS.

The samples were packed in paper bags and dried in an oven with forced air ventilation for 72 hours at $55^{\circ} \mathrm{C}$. After drying, samples were ground in a Willey mill, with a $1 \mathrm{~mm}$ sieve and submitted to laboratory procedures to determine DM (method 934.01), crude protein (CP; method 984.13), according to AOAC (1990). Neutral detergent fiber (NDF) and acid detergent fiber (ADF) were determined according to Van Soest et al. (1991). Sodium sulfite and $\alpha$-amylase were used during NDF determination. Lignin (LIG) analyses were performed on ADF residues, using the direct sulfuric acid method (ROBERTSON; VAN SOES, 1981). Neutral detergent insoluble nitrogen (NDIN) and acid detergent insoluble nitrogen (ADIN) were determined based on the methodology described by Licitra et al. (1996). Neutral detergent insoluble protein (NDIP) and acid detergent insoluble protein (ADIP) were calculated by multiplying the values of ADIN and NDIN by 6.25. Hemicellulose was determined by subtracting ADF from NDF and cellulose was calculated as ADF minus LAS. Soluble carbohydrates determination was obtained as described by Johnson et al. (1966), with a spectrophotometric reading taken at a wavelength of $480 \mathrm{~nm}$.

\section{Temperatures and moisture}

During the storage period, temperatures and the moisture content of both hay and environment were measured during the 60 days with a skewer digital thermometer (Center 370 provides) and a hay moisture meter (Delmhorst FX-2000 Digital). Samples from each bale were also daily collected (5 samples per treatment) to determine the DM contents.

\section{In vitro digestibility of dry matter (IVDMD)}

The technique described by Tilley and Terry (1963) was adopted to determine IVDMD, after adapting to the Artificial Rumen TE-150 (Tecnal, scientific equipment, Piracicaba, SP, Brazil) as described by Holden (1999). Rumen fluid was obtained from 2 donor Jersey bulls of approximately $500 \mathrm{~kg}$ with a permanent ruminal cannula. The collection of ruminal fluid was performed in the morning before the first meal, using a vacuum pump and a vacuum flask with a capacity of 2000 $\mathrm{mL}$. Ruminal fluid was kept in a water bath at $39^{\circ} \mathrm{C}$ and the container purged with $\mathrm{CO}_{2}$ before and after collection. The extracts were filtered through four layers of cotton cloth and used in the incubations. The buffer solution was prepared with the following reagents: Solution A (g L $\left.{ }^{-1}\right): 10.0 \mathrm{~g} \mathrm{KH}_{2} \mathrm{PO}_{4}$; $\mathrm{MgSO}_{4} 7 \mathrm{H}_{2} \mathrm{O} 0.5 \mathrm{~g} ; 0.5 \mathrm{~g} \mathrm{NaCl} ; 0.1 \mathrm{~g} \mathrm{CaCl}_{2} 2 \mathrm{H}_{2} \mathrm{O}$; $0.5 \mathrm{~g}$ urea and solution $\mathrm{B}\left(\mathrm{g} \mathrm{dL}^{1}\right): 15.0 \mathrm{~g} \mathrm{Na}_{2} \mathrm{CO}_{3}$; $1.0 \mathrm{~g} \mathrm{Na} \mathrm{S}_{2} . \mathrm{H}_{2} \mathrm{O}$. The solutions were mixed in a $1: 5$ ratio, resulting in a $\mathrm{pH}$ of 6.8 at $39^{\circ} \mathrm{C}$ constant temperature. -

\section{Statistical analyses}

Dates were analyzed using the statistical software Sisvar 5.0 (FERREIRA, 2011). Data of the dehydration curve were subjected to ANOVA and Fisher $\mathrm{F}$ test. When there was a significant effect of dehydration time, a regression analysis was 
conducted. For the choice of model, the highest coefficient of determination (R2) was considered.

Gas exchange was evaluated before cutting (time point 0 ) and at, 14 and 18 hours after cutting, with the measuring times considered as fixed effects. To determine the nutritional value, the two storage environments of hay bales (open-SO and closed$\mathrm{CS})$ and three storage times (30, 60, and 90 days) were evaluated. The storage environments and times were considered fixed effects, whereas the bales were considered random effects. The times and days were considered as repeat measurements.

The restricted maximum likelihood method was used to estimate the components of variance. The time-series covariance structure was selected based on the lowest values of the AIC (Akaike's Information Criterion), BIC (Bayesian Information Criterion) and Bayesian information criteria. The PDIFF option adjusted by the Tukey method was included in the LSMEANS instruction to consider multiple comparisons. The effects were considered significant at $\alpha=0.05$.

\section{Results}

Immediately after cutting, Bermudagrass showed changes in the DM contents, with little rehydration of the plants in the morning due to dew. The dehydration rate in different parts of the plant was also shown to differ significantly as the leaves showed higher DM at the evaluated times. The DM contents obtained during the dehydration followed at $3^{\text {rd }}$ degree polynomial model.
During cutting, Bermudagrass showed a DM of $245.01 \mathrm{~g} \mathrm{~kg}^{-1}$ for the whole plant, with the leaf portion presenting a DM of $289.98 \mathrm{~g} \mathrm{~kg}^{-1} \mathrm{DM}$ and the stem portion $233.92 \mathrm{~g} \mathrm{~kg}^{-1} \mathrm{DM}$. After 44 hours of dehydration in the field, the DM contents were $903.12 \mathrm{~g} \mathrm{~kg}^{-1}$ for the whole plant, $913.20 \mathrm{~g} \mathrm{~kg}^{-1}$ for leaf and $825.22 \mathrm{~g} \mathrm{~kg}^{-1}$ for the stem. Thus, the leaf showed the highest DM content (Figure 1).

An influence of cutting caused by mower conditioner was observed on variables such as gas exchange of Bermudagrass leaves (Cynodon dactylon) during the studied period. In general, the highest average values were obtained before cutting, except for $L R$. Bermudagrass cutting caused a drastic decrease in the $P n$ rates of leaves after cutting. However, there was no change in $L R$ $(\mathrm{P}>0.05)$ from cutting until 14 hours. Negative values of $P n 14$ hours after cutting indicated high rates of respiration. Transpiration ( $T r$ ) showed some decrease 18 hours after cutting and the same occurred with the Gs. Values of WUE decreased after 14 hours but increased 18 hours after cutting (Table 2).

Under the tested conditions, 18 hours after cutting (600 $\left.\mathrm{g} \mathrm{kg}^{-1} \mathrm{DM}\right)$ was sufficient to extract the majority of water from the leaves and stems via stomatal and cuticular $T r$. The $G s, P n$ and $T r$ values were close to zero. However, the optimal DM content of the whole plant for baling (891.1 g $\mathrm{kg}^{-1}$ ) was reached with 44 hours of dehydration. 
Figure 1. Dehydration curve of the whole plant, leaf, and stem of Bermudagrass.

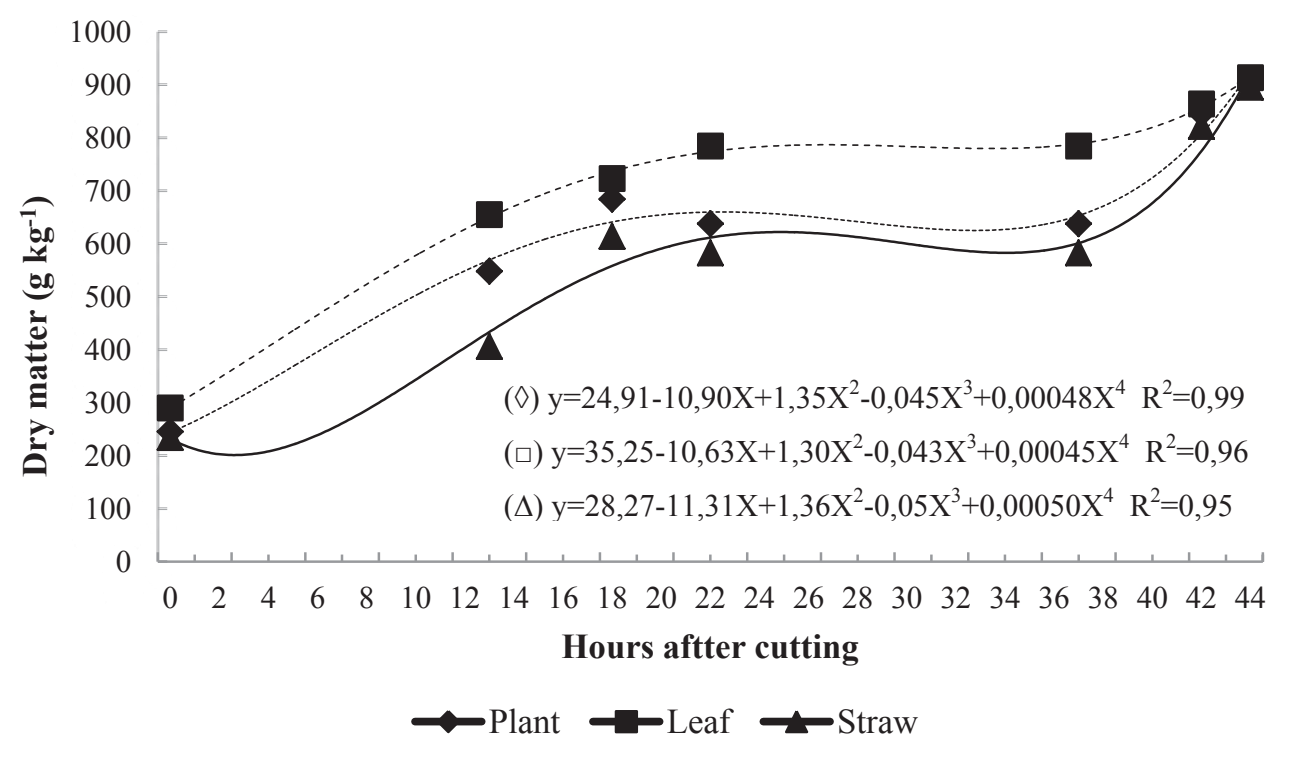

Table 2. Photosynthesis $(P n)$, transpiration $(E)$, stomatal conductance $(G s)$, water use efficiency (WUE) and leaf respiration $(L R)$ at 0,14 and 18 hours after Bermudagrass cutting (Cynodon dactylon).

\begin{tabular}{cccccc}
\hline Times (hours) & $P n$ & $T r$ & $G s$ & WUE & $L R$ \\
\hline 0 & $13.30 \mathrm{a}$ & $5.53 \mathrm{a}$ & $0.27 \mathrm{a}$ & $2.45 \mathrm{a}$ & $-4.29 \mathrm{~b}$ \\
14 & $-4.37 \mathrm{c}$ & $4.07 \mathrm{~b}$ & $0.23 \mathrm{a}$ & $-1.11 \mathrm{~b}$ & $-5.66 \mathrm{~b}$ \\
18 & $1.13 \mathrm{~b}$ & $0.37 \mathrm{c}$ & $0.01 \mathrm{~b}$ & $3.21 \mathrm{a}$ & $1.33 \mathrm{a}$ \\
\hline LSD & 2.12 & 0.96 & 0.09 & 1.58 & 2.34 \\
\hline AS & 817.47 & 70.70 & 0.20 & 53.20 & 137.21 \\
\hline
\end{tabular}

Pn: $\mu \mathrm{mol} \mathrm{CO} \mathrm{m}^{-2} \mathrm{~s}^{-1} ; \mathrm{Tr}: \mathrm{mmol} \mathrm{H} \mathrm{O} \mathrm{m}^{-2} \mathrm{~s}^{-1} ;$ Gs: $\mathrm{mol} \mathrm{m}{ }^{-2 \mathrm{~s}-1} ; W U E: \mu \mathrm{mol} \mathrm{CO} \mathrm{m}^{-2} \mathrm{~s}_{2}^{-1 / \mathrm{H}} \mathrm{O}_{\mathrm{mmol} \mathrm{m}}^{-2 \mathrm{~s}-1}$ and $L R: \mu \mathrm{mol} \mathrm{CO}_{2} \mathrm{~m}^{-2} \mathrm{~s}^{-1}$. Averages followed by the same letter in columns do not differ by Tukey test at $\alpha=0.05$. LSD: Least significant difference; AS: Average Square.

Difference $(\mathrm{P}<0.05)$ between the DM contents at 30 and 90 days of storage were observed in OS. The lowest DM values were observed at the time of cutting. There were no differences $(\mathrm{P}>0.05)$ in the DM contents evaluated for OS and CS at 30 and 60 days, whereas after 90 days of storage the hay in CS showed a higher DM content compared to the stored in OS (Table 3).

The CP contents ranged from 134.60 to 181.80 $\mathrm{g} \mathrm{kg}^{-1}$ with interaction between storage and time systems. There was a significant decrease $(\mathrm{P}<0.05)$ for both OS and CS in relation to the cutting time and the other evaluated times of storage. There was also a difference $(\mathrm{P}<0.05)$ between the storage times in OS storage environment. At 60 and 90 days of storage, there was a significant decrease in $\mathrm{CP}$ compared to that at 30 days of storage, whereas in $\mathrm{CS}$, there was no change in response to the different storage times. There were no differences on $\mathrm{CP}$ contents between the two storage environments (Table 3).

The NDF levels ranged from 711.6 at the time of cutting to 726.50 and $709 \mathrm{~g} \mathrm{~kg}^{-1} \mathrm{DM}$ at 90 days of storage, in the OS and CS environments, respectively. These values were considered high in comparison to tropical fodder hay (NERES et al., 
2011). There was a reduction in the levels of ADF in the OS environment, after 90 days of fermentation. The ADF content was lower in CS compared to OS.

The NDIP contents were higher $(\mathrm{P}<0.05)$ at 90 days of storage for two environments evaluated OS and CS. There was no effect $(\mathrm{P}>0.05)$ between the environments. The ADIP content increased $(\mathrm{P}$
$<0.05)$ from the cutting with respect to the ensiled mass. The ADIP content was no affected $(\mathrm{P}>0.05)$ by time of fermentation. The NDIP and ADIP content also differed between storage environments (OS and CS) after 60 days of storage and were higher in the OS.

Table 3. Nutritional value of Bermudagrass (Cynodon dactylon) at cutting time, 30,60 and 90 days of storage in open shed (OS) and in the closed shed (CS).

\begin{tabular}{|c|c|c|c|c|c|c|c|}
\hline \multirow{2}{*}{ Nutrients $\left(\mathrm{g} \mathrm{kg}^{-1}\right)$} & \multirow{2}{*}{ Shed } & \multirow{2}{*}{ Cutting } & \multicolumn{3}{|c|}{ Days of storage } & \multirow{2}{*}{$\begin{array}{l}\text { CV1 } \\
(\%) \\
\end{array}$} & \multirow{2}{*}{$\begin{array}{c}\text { CV2 } \\
(\%)\end{array}$} \\
\hline & & & 30 & 60 & 90 & & \\
\hline \multirow{2}{*}{ Dry Matter, DM } & OS & $236.4 \mathrm{c}$ & $838.1 \mathrm{aA}$ & $826.0 \mathrm{abA}$ & $803.2 \mathrm{bB}$ & \multirow{2}{*}{1.75} & \multirow[t]{2}{*}{2.21} \\
\hline & $\mathrm{CS}$ & $236.4 b$ & $846.1 \mathrm{aA}$ & $836.5 \mathrm{aA}$ & $840.4 \mathrm{aA}$ & & \\
\hline \multirow{2}{*}{ Crude Protein, CP } & OS & $181.8 \mathrm{a}$ & $170.3 b$ & $134.6 \mathrm{c}$ & $154.5 \mathrm{bc}$ & \multirow[t]{2}{*}{8.47} & \multirow[t]{2}{*}{10.15} \\
\hline & $\mathrm{CS}$ & $181.8 \mathrm{a}$ & $153.2 \mathrm{~b}$ & $140.0 \mathrm{~b}$ & $159.7 \mathrm{~b}$ & & \\
\hline \multirow{2}{*}{ Acid Detergent Fiber, ADF } & OS & $320.3 \mathrm{c}$ & $393.5 \mathrm{aA}$ & $374.8 \mathrm{abA}$ & $373.8 \mathrm{bA}$ & \multirow[t]{2}{*}{1.31} & \multirow[t]{2}{*}{3.13} \\
\hline & $\mathrm{CS}$ & $320.3 \mathrm{~d}$ & $391.4 \mathrm{aA}$ & $367.2 \mathrm{bA}$ & $347.9 \mathrm{cB}$ & & \\
\hline \multirow{2}{*}{ Neutral detergent insoluble protein, NDIP } & OS & $72.00 \mathrm{~b}$ & $81.5 b$ & $76.9 \mathrm{~b}$ & $95.1 \mathrm{a}$ & \multirow[t]{2}{*}{4.61} & \multirow[t]{2}{*}{8.73} \\
\hline & $\mathrm{CS}$ & $72.00 \mathrm{~b}$ & $73.7 \mathrm{~b}$ & $82.1 \mathrm{~b}$ & $96.9 \mathrm{a}$ & & \\
\hline \multirow{2}{*}{ Acid detergent insoluble protein ADIP } & OS & $37.00 \mathrm{~b}$ & $60.5 \mathrm{aA}$ & $64.9 \mathrm{aA}$ & $50.5 \mathrm{aA}$ & \multirow[t]{2}{*}{36.03} & \multirow[t]{2}{*}{21.74} \\
\hline & $\mathrm{CS}$ & $37.00 \mathrm{~b}$ & $45.2 \mathrm{aA}$ & $43.3 \mathrm{aB}$ & $45.6 \mathrm{aA}$ & & \\
\hline \multirow{2}{*}{ Lignin } & OS & $56.90 \mathrm{c}$ & $88.1 \mathrm{abA}$ & $74.7 \mathrm{bB}$ & $99.0 \mathrm{aA}$ & \multirow[t]{2}{*}{17.84} & \multirow[t]{2}{*}{10.73} \\
\hline & $\mathrm{CS}$ & $56.90 \mathrm{c}$ & $91.5 \mathrm{aA}$ & $93.5 \mathrm{aA}$ & $75.1 \mathrm{bB}$ & & \\
\hline \multirow{2}{*}{ Cellulose } & OS & $263.4 \mathrm{c}$ & $305.3 \mathrm{aA}$ & $300.0 \mathrm{aA}$ & $274.8 \mathrm{bA}$ & \multirow[t]{2}{*}{4.34} & \multirow[t]{2}{*}{3.20} \\
\hline & $\mathrm{CS}$ & $263.4 \mathrm{c}$ & 299.9aA & $273.7 \mathrm{bB}$ & $272.7 \mathrm{bA}$ & & \\
\hline \multirow{2}{*}{ Soluble Carbohydrates } & OS & $30.38 \mathrm{a}$ & $34.9 \mathrm{a}$ & $23.7 b$ & $17.9 \mathrm{~b}$ & \multirow[t]{2}{*}{21.32} & \multirow[t]{2}{*}{22.55} \\
\hline & $\mathrm{CS}$ & $30.38 \mathrm{a}$ & $32.0 \mathrm{a}$ & $23.12 \mathrm{ab}$ & $22.2 b$ & & \\
\hline
\end{tabular}

Means followed by different lowercase letters in row and different uppercase letters in column differ statistically by Tukey test at $\alpha=0.05$. CV1 $=$ coefficient of variation of the plots; $\mathrm{CV} 2=$ coefficient of variation of the subplots.

Lignin increased in the OS environment from 60 to 90 days of storage. In the CS, the lignin contents were reduced $(\mathrm{P}<0.05)$ with 90 days of storage (Table 3). The cellulose contents were reduced in response to storage time in both evaluated environments (OS and $\mathrm{CS}$ ), but at 60 days, the OS system presented higher levels compared to the CS system (300.0 and $273.7 \mathrm{~g} \mathrm{~kg}^{-1} \mathrm{DM}$, respectively). The hemicellulose content did not present differences $(\mathrm{P}>0.05)$ in any of the evaluated time or storage systems. The mean hemicellulose contents for OS and CS were 372.2 and $362 \mathrm{~g} \mathrm{~kg}^{-1} \mathrm{DM}$, respectively (Table 3 ).
The carbohydrate concentration was higher at 30 days of storage with an average of $33.43 \mathrm{~g} \mathrm{~kg}^{-1}$ DM and did not differ from the contents obtained at cutting time. There was a decrease in soluble carbohydrates content at 60 days of storage, in both $\mathrm{OS}$ and CS. There was a significant difference (P $<0.05$ ) between the concentration at cutting time and after 90 days of storage in both, OS and CS environments. The average soluble carbohydrate content was $30.38 \mathrm{~g} \mathrm{~kg}^{-1} \mathrm{DM}$ and decreased to 17.90 $\mathrm{g} \mathrm{kg}^{-1} \mathrm{DM}$ in OS, while in CS, the final content was $22.18 \mathrm{~g} \mathrm{~kg}^{-1} \mathrm{DM}$. However, there was no difference 
$(\mathrm{P}>0.05)$ between storage environments. The IVDMD of Bermudagrass did not differ significantly $(\mathrm{P}>0.05)$ among the evaluated times and storage systems.

It was observed that the temperature of bales was always less than or equal to the environmental temperature, for both OS and CS (Figure 2 and
3). The observed increase in the humidity of the environment in the two storage systems evaluated was at consequence of the rain, because the experiment was carried out during the wet period. The moisture in bales did not exceed $10 \%$ in either environments, except on the $15^{\text {th }}$ day of storage in CS (Figure 3).

Figure 2. Temperature and moisture of hay from the $1^{\text {st }}$ to the $60^{\text {th }}$ day of storage in the open shed.
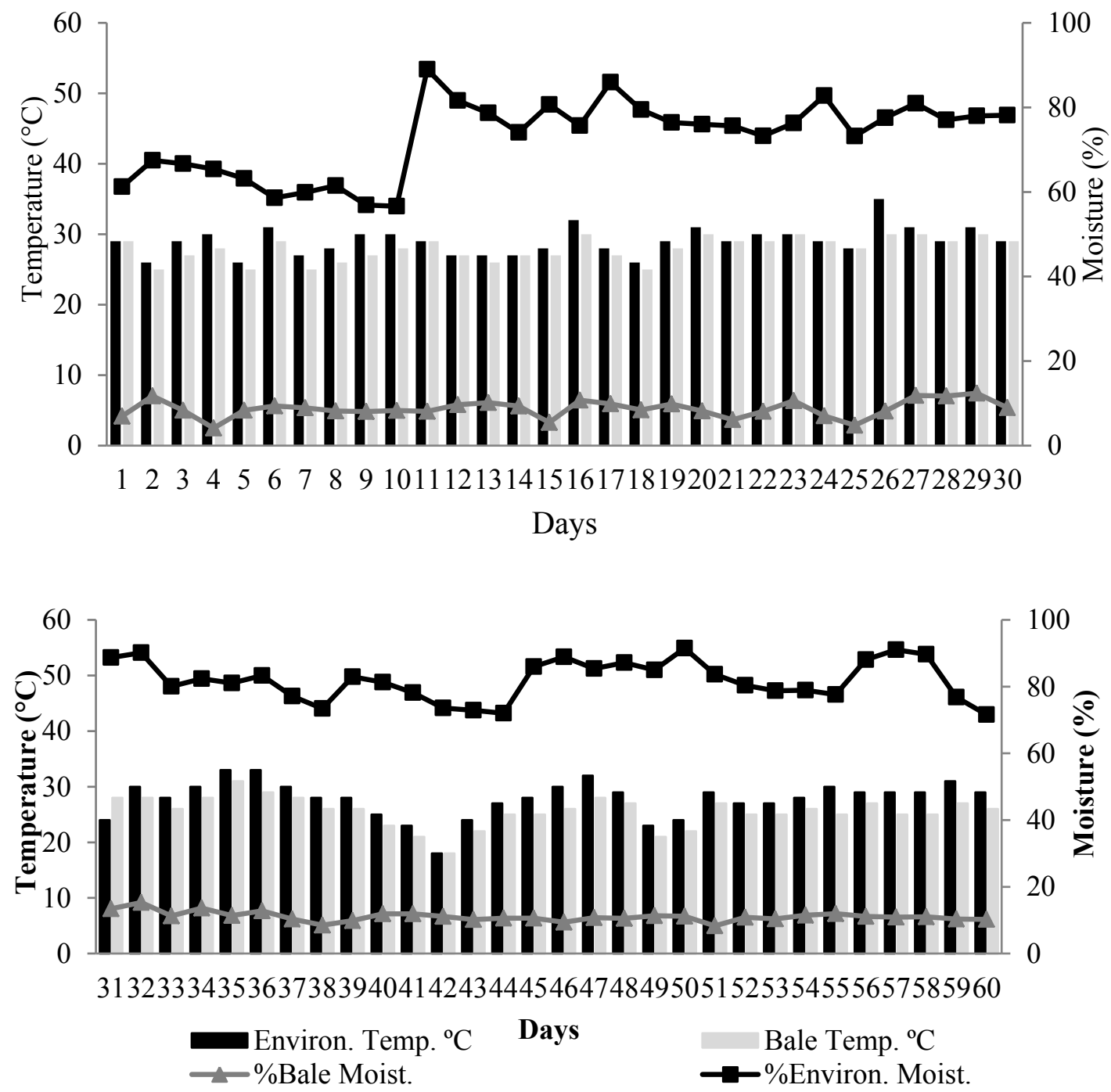
Figure 3. Temperature and moisture of hay from the $1^{\text {st }}$ to the $60^{\text {th }}$ day of storage in the closed shed $(\mathrm{CS})$.

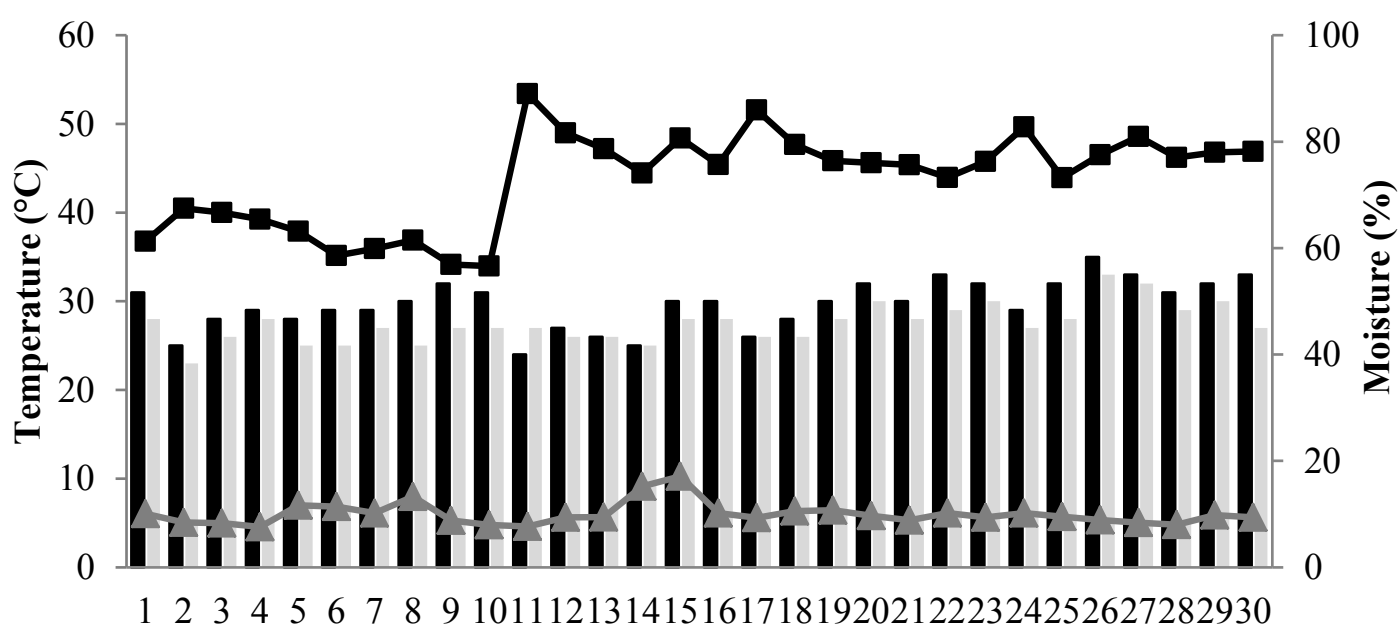

Days

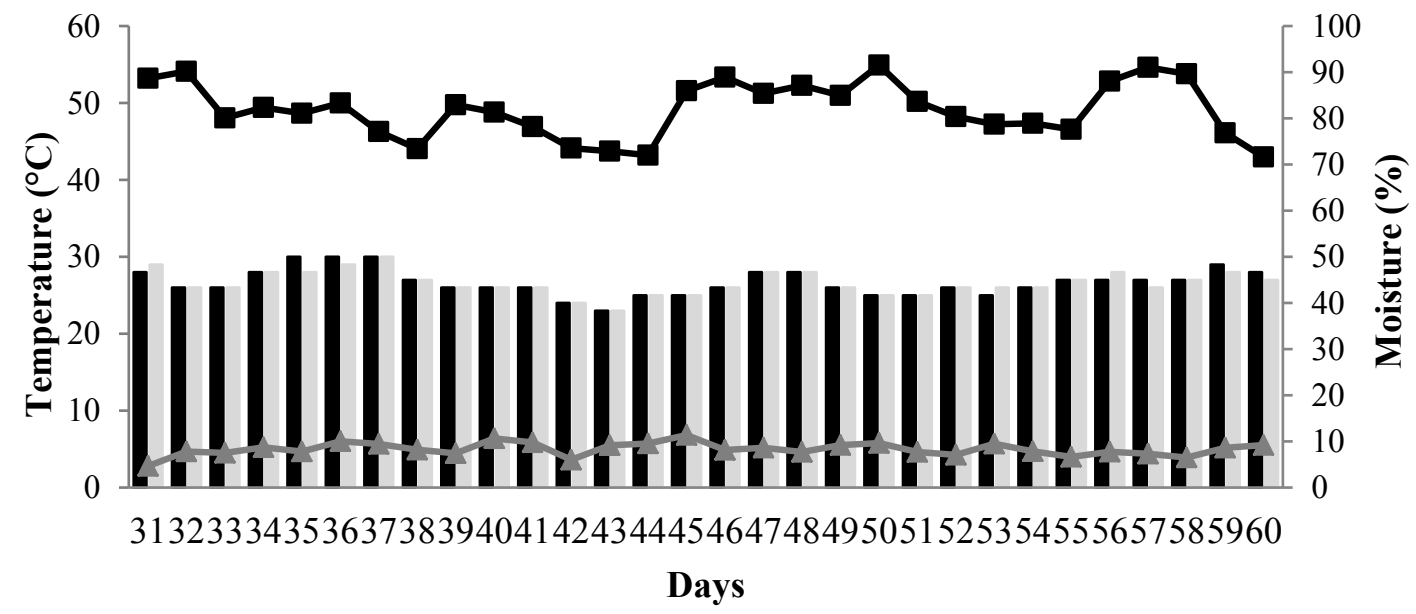

Environ. Temp. ${ }^{\circ} \mathrm{C}$ Bale Temp. ${ }^{\circ} \mathrm{C} \rightarrow \%$ Bale Moist. $\rightarrow$ Environ. Moist.

\section{Discussion}

At baling time, DM contents of the whole plant ranged between, 800-900 $\mathrm{g} \mathrm{kg}^{-1}$. The hay is considered safe for storage at less than $20 \%$ moisture to prevent mold, heating, as well as DM and nutrient losses (COLLINS; OWENS, 2003). Notably, the dehydration period did not exceed 7 days, which according to Collins (1995), would be the timeout to produce hay appropriate for animal consumption.
The leaves showed the highest and fastest rate of dehydration in the plant because of their lowest initial moisture content. They also lose much water due to the presence of stomata, facilitating rapid dehydration in the first hours after forage cutting. The faster rate of dehydration of Bermudagrass is a result of its stem diameter of $0.64 \mathrm{~mm}$, which is considered ideal to accelerate dehydration. According to Neres et al. (2017), stem diameter is negatively correlated with forage dehydration rate. Higher measures for this structural feature were determined by Calixto 
Júnior et al. (2007), who obtained stem diameter of $1.98 \mathrm{~mm}$ with a dehydration rate of $100 \mathrm{~kg} \mathrm{ha}^{-1}$ and with $\mathrm{N}$ fertilization, a stem diameter of $1.95 \mathrm{~mm}$ with $50 \mathrm{~kg} \mathrm{ha}^{-1}$ for the Cynodon Bermudagrass.

The dehydration curve of the plant, leaf, and stem presented, diurnal fluctuations in dry matter content in period from 0 to 44 hours after cutting, similar to that described by Calixto Júnior et al. (2007). These fluctuations are caused by the loss of moisture during the day, which is partially replaced from the air during the night as humidity levels rise or by dew (COLLINS; OWENS, 2003). However, the amount of moisture acquired during nighttime was low and it was quickly evaporated with a few hours of sunshine (CALIXTO JÚNIOR et al., 2007; PASQUALOTTO et al., 2015). Notably, even though the plant cutting was done at 19.00 hours, during night (13 hours), the plants lost $32.29 \%$ of their total water content through evaporation.

Gas exchange was more intense until 14 hours after cutting, which could be attributed to the fact that stomatal conductance increased after cutting due to water vapor output, caused by injuries in the leaf cuticle and not just stomata, which are probably closed. This fact changed the decrease in the WUE variable, since the lowers rate was observed during the first 14. Lavezzo and Andrade (1994) have already considered, that in the first phase, the dehydration is fast, resulting in severe water loss. The decrease in moisture was approximately 80 to $85 \%$, where most of the water loss is caused by transpiration.

Future studies on this aspect should valuations should be carried out at shorter intervals to better characterize the exact moment of transition regarding water evaporation/loss via stomata and cuticle in Bermudagrass plants. Water loss is maximized during cutting time by injuries to the plant tissues that are aimed at accelerating the water evaporation/loss and reducing baling time.

Dry matter loss during the first weeks of storage is result of a temperature increases caused by microorganisms present in the hay. The respiration process utilizes soluble carbohydrates, present in hay, and produces $\mathrm{CO}_{2}$ and water, causing the reduction in DM by approximately 4 - 5\%; however, this loss does not always affect hay quality. In general, after hay has reached its equilibrium moisture in the storage, for a loss of $1 \%$ of its original moisture at baling, there will be a corresponding loss of $1 \% \mathrm{DM}$ (COLLINS et al., 1997).

The climatic conditions seem to have affected the DM loss in the OS storage system compared to the CS system. According to Raymond et al. (1978), hay is hygroscopic, therefore it can absorb and lose water to the environment; thus, its DM content is influenced by relative humidity conditions. According to Rotz and Muck (1994), as storage time increases, the DM loss also increases.

Soluble carbohydrates content at the time of cutting was approximately $30.38 \mathrm{~g} \mathrm{~kg}^{-1} \mathrm{DM}$. These values were lower than those described by Ribeiro et al. (2001) in a study using Tifton 85 for hay production, where the soluble carbohydrate content was on average $40.36 \mathrm{~g} \mathrm{~kg}^{-1} \mathrm{DM}$. Tropical grasses are naturally low in soluble carbohydrates.

Cellular respiration occurs through the consumption of soluble carbohydrates during the dehydration process of plants. However, changes in the content of soluble carbohydrates also occur in the storage period, as, the action of microorganisms can lead at decrease in carbohydrates content (COLLINS et al., 1997), as previously mentioned.

The reduction in CP content observed in both evaluated environments from the time of cutting up to 30 days after baling, is caused by proteolysis resulting from the respiratory activity still present in the plants after cutting. This process occurs naturally, and the presence of water causes the proteolysis to occur very quickly, so the extent of degradation is influenced by the drying time (MOSER, 1980). Therefore, the rapid dehydration of forage decreases proteolysis, as causes inactivation of the proteases, which are the enzymes that break peptide bonds between the amino acids of the proteins. 
During storage time, at reduction in CP content occurred mainly in the OS, being more evident after 90 days of storage. Segundo Neres et al. (2014) and Pasqualotto et al. (2015) stated that during long-term storage, $\mathrm{CP}$ concentration is expected to decrease by $0.25 \%$ per month due to the volatilization process. Additionally, this effect can be influenced by environmental factors such as temperature and humidity, which can cause the forage protein to bind to the cell wall of the plant, through a Maillard reaction, making this protein unavailable (MOSER, 1980; CAPUANO et al., 2008). The Maillard reaction is a heat-induced chemical reaction between proteins (amino acids) and sugars as a result of which this protein becomes unavailable (CAPUANO et al., 2008).

The ambient temperature during the evaluation time remained close $28^{\circ} \mathrm{C}$, in both $\mathrm{OS}$ and $\mathrm{CS}$ environments. At the storage times evaluated (30, 60 and 90 days), the bale temperature was below room temperature, both in OS and CS. According to Moser (1980) and Van Soest (1994), temperatures above $55^{\circ} \mathrm{C}$ can reduce digestibility by up to $14 \%$, but temperatures below $48^{\circ} \mathrm{C}$ generally do not alter hay digestibility.

Ames et al. (2014) monitored both bale and ambient temperatures in CS and observed that bales prepared with Tifton $85+$ pea had a higher temperature up to the 14th day of storage due to the high moisture content of the pea (774 $\left.\mathrm{g} \mathrm{kg}^{-1} \mathrm{DM}\right)$ in the baling. After this time, the bale temperature remained near room temperature.

Environmental humidity was below $70 \%$ by day 10 of bale storage. After day 10 of evaluation, the moisture increased to more than $80 \%$ in both environments. Moisture content in the bales is one of the main factors to evaluate when assessing the quality of stored hay. Moisture inside the bales remained below 15\%. According to Collins (1995), even at $<15 \%$ moisture, microbial respiration can remarkably reduce the quality of the bale of stored hay, as it allows the development of microorganisms.
An increase in ADIN content occurred after 60 days of storage, with the highest values observed in the OS. Coblentz et al. (2000) suggest that this increase is associated with warming and at reduction in the concentration of soluble carbohydrates in the hay during the storage time (YANG et al., 1993), reducing hay quality and directly affecting the digestibility of hay (WUNSCH et al., 2007). In the present study, the NDIN content increased after 90 days of storage but did not present differences between the evaluated environments. This indicates that changes do not occur only in the first 30 days of storage, which is important information for farmers who get hay from distances places and therefore store them for longer periods.

The NDF results in this study were similar between storage and time systems. Consistent with the results obtained by Neres et al. (2011) for Tifton 85 hay. The authors obtained NDF values at cutting time of $77.77 \mathrm{~g} \mathrm{~kg}^{-1}$ and after 30 days of storage, in a $\mathrm{CS}$, the NDF values were $78.22 \mathrm{~g} \mathrm{~kg}^{-1}$. The changes in $\mathrm{ADF}$ values between the cutting time and the first period of storage and their decreased values may be associated with the changes in fibrous components and must be due to the DM losses that occur naturally in stored hay (BUCKMASTER et al., 1989). However, they increased at 90 days indicating that significant changes in nutritional components may occur during long term storage.

The lignin content is an important component to be described since it describes the digestibility of the fiber in the rumen. In this experiment, an increase in lignin contents occurred up to 90 days after storage in the $\mathrm{CO}$, and up to 60 days of storage in the CS, which may be related to the loss of available nutrients (proteins, soluble carbohydrates, minerals and vitamins) (TURNER et al., 2002). However, $I V \mathrm{DMD}$ was not affected by the increase of the lignin content in hay.

The increase in cellulose content from the cutting time to 30 days into storage was also seen by Taffarel et al. (2014) and Neres et al. (2011), 
who also evaluated Tifton 85 hay. However, Ames et al. (2014), obtained lower values for cellulose at 30 days of Tifton 85 storage and higher values at the cutting time. The decreased cellulose behavior after 30 days of storage can be due to the decrease in ADF contents, as cellulose and lignin are the most important constituents of ADF.

Hemicellulose content showed no difference $(\mathrm{P}>$ $0,05)$ among the storage times and may be related to NDF, which also remained stable during the storage period. Only a small decrease in hemicellulose content was observed, a behavior that could be explained by the increased ADF content. Regarding the hemicellulose content, the results of this study similar to that reported by Taffarel et al. (2014) who evaluated Tifton 85 hay with 35 days of regrowth at the cutting time, baling and 30 days after baling. The highest values of hemicellulose content occurred at the cutting time and the lowest values at 30 days of storage. According to Van Soest (1994) this behavior is common, as hemicellulose is a heterogeneous collection of amorphous polysaccharides with a much lower degree of polymerization compared to cellulose and the decrease in its content in stored hay is partly due to the expansion of cellulose.

The digestibility results were on average 725.66 and $745.16 \mathrm{~g} \mathrm{~kg}^{-1}$ for OS and CS, respectively. These results are higher than the values described by Ames et al. (2014), who evaluated different ways of managing Tifton 85 with 110 days of regrowth during winter and concluded that the mean IVDMD was $466.20 \mathrm{~g} \mathrm{~kg}^{-1}$ at the cut-off time and 376.00 $\mathrm{g} \mathrm{kg}^{-1} \mathrm{DM}$ in one sample collected at 30 days of storage in CS. This difference could be attributed to the age difference of the plants (110 days of growth).

\section{Conclusions}

The transpiration rate decreases from the cutting time to 14 hours after cutting, when cutting is carried out in the afternoon. The nutritional value of hay is affected by the environment and storage time. The open system (OS) caused higher losses of DM and an increase of ADF and lignin content, compared to the closed environment (CS). The loss in CP content and soluble carbohydrates as well as an increase in NDIP was evident starting from 30 days of storage. However, these effects on the nutritional value were not reflected in the IVDMD of hay until 90 days of storage.

\section{Conflicts of interest}

The authors declare they have no conflicts of interest with regard to the work presented in this report.

\section{References}

AMES, J. P.; NERES, M. A.; CASTAGNARA, D. D.; MUFATTO, L. M.; DUCATI, C.; JOBIM, C. C. TRES, T. T. Dry matter production, chemical composition, dry matter digestibility and occurrence of fungi in bermudagrass hay (Cynodon dactylon) under different fertilization systems or associated with pea planting in winter. Ciencia e Investigación Agraria, Santiago, v. 41, n. 2 , p. $163-174,2014$. DOI: $10.4067 / \mathrm{S} 0718-$ 16202014000200003.

ASSOCIATION OF OFFICIAL ANALYTICAL CHEMISTS - AOAC. Official methods of analysis. $15^{\text {th }}$ ed. Washington: Association of Official Analytical Chemists, 1990.

BUCKMASTER, D. R.; ROTZ, C. A.; MERTENS, D. R. A. Model of alfalfa hay storage. Transactions of the ASAE, Michigan, v. 32, n. 1, p. 30-36, 1989. DOI: $10.13031 / 2013.30958$.

BURTON, G. W.; GATES, R. N.; HILL, G. M. Registration of Tifton 85 bermudagrass. Crop Science, Madison, v. 33, n. 3, p. 644-645, 1993. DOI: $10.2135 /$ cro psci1993.0011183X003300030045x.

CALIXTO JÚNIOR, M.; JOBIM, C. C.; CANTO, M. W. Taxa de desidratação e composição químicobromatológica do feno de grama-estrela (Cynodon nlemfuensis Vanderyst) em função de níveis de adubação nitrogenada. Semina: Ciências Agrárias, Londrina, v. 28, n. 3 , p. $493-502$, 2007. DOI: $10.5433 / 1679-0359.2007 \mathrm{v} 2$ 8n3p493.

CAPUANO, E.; FERRIGNO, A.; ACAMPA, I.; AITAMEUR, L.; FOGLIANO, V. Characterization of the Maillard reaction in bread crisps. European Food Research and Technology, Munich, v. 228, n. 2, p. 311- 
319, 2008. DOI: 10.1007/s00217-008-0936-5.

COBLENTZ, W. K.; TURNER, J. E.; SCARBROUGH, D. A.; LESMEISTER, K. E.; JOHNSON, Z. B.; KELLOGG, D. W.; COFFEIY, K. P.; MCBETH, L. J.; WEYERS, J. S. Storage characteristics and nutritive value changes in bermudagrass hay as affected by moisture content and density of rectangular bales. Crop Science, Madinson, v. 40, n. 5, p. 1375-1383, 2000. DOI: 10.2135/cropsci2000.4051375x

COLLINS, M. Hay preservation effects on yield and quality. In: MOORE, K. J.; KRAL, D. M.; VINEY, M. K. Post-harves tphysiology and preservation of forages. Madison: American Society of Agronomy, 1995. p. 6789.

COLLINS, M.; OWENS, V. Preservation of forages as hay and silage. In: BARNES, R. F.; NELSON, C. J.; MOORE, K. J. Forages: an introduction to grassland agriculture. Ames: Iowa State Univ. Press, 2003. p. 443471.

COLLINS, D. W.; MAYDEW, E. L.; WEISS, I. S. Changes in the value-relevance of earnings and book values over the past forty years. Journal of Accounting \& Economics, Utah, v. 24, n.1, p. 39, 1997. DOI: 10.1016/ S0165-4101(97)00015-3.

EMPRESA BRASILEIRA DE PESQUISA AGROPECUÁRIA - EMBRAPA. Sistema brasileiro de classificação de solos. Rio de Janeiro: EMBRAPA Solos, 2006.

FERREIRA, D. F. Sisvar: a computer statistical analysis system. Ciência e Agrotecnologia, Lavras, v. 35, n. 6, p. 1039-1042. 2011. DOI: 10.1590/S141370542011000600001 .

HOLDEN, L. A. Comparison of methods of in vitro dry matter digestibility for ten feeds. Journal of Dairy Science, Madison, v. 82, n. 8, p. 1791-1794, 1999. DOI: 10.3168/jds.S0022-0302(99)75409-3

JOHNSON, R. R.; BALWANI, T. L.; JOHNSON, L. J.; MCCLURE, K. E.; DEHORITY, B. A. Corn plant maturity. II. Effect on in vitro cellulose digestibility and soluble carbohydrate content. Journal of Animal Science, Champaign, v. 25, n. 3, p. 617-623, 1966. DOI:10.252/ jas 1966.253617x.

LAVEZZO, W.; ANDRADE, J. B. Conservação de forragens: feno e silagem. In: SIMPÓSIO BRASILEIRO DE FORRAGENS E PASTAGENS, 1994, Campinas. Anais... Campinas: Colégio Brasileiro de Nutrição Animal, 1994. p. 105-166.

LICITRA, G.; HERNANDEZ, T. M.; VAN SOEST, P. J. Standardization of procedures for nitrogen fractionation of ruminant feeds. Animal Feed Science and Technology, New York, v. 5, n. 4, p. 347-358, 1996. DOI: 10.1016/0377-8401(95)00837-3

MOSER, L. E. Quality of forages as affected by postharvest storage and processing. In: HOVELAND, C. S. Crop quality storage, and utilization. Madison: American Society of Agronomy, 1980. p. 227-260.

NERES, M. A.; CASTAGNARA, D. D.; MESQUITA, E. E.; JOBIM, C. C.; TRÊS, T. T.; OLIVEIRA, P. S. R.; OLIVEIRA, A. A. M. A. Production of tifton 85 hay over seeded with white oats or ryegrass. Revista Brasileira de Zootecnia, Viçosa, MG, v. 40, n. 8, p. 1638-1644, 2011. DOI: $10.1590 / \mathrm{S} 1516-35982011000800003$.

NERES, M. A.; CASTAGNARA, D. D.; MUFFATO, L. M.; FERNANDES, T.; HUNOFF, C. A.; WOBETO, J. R.; NATH, C. D. Changes in Tifton 85 bermudagrass hay storage in the field or under shed. Archivos de Zootecnia, Córdoba, v. 63, n. 243, p. 555-558, 2014. DOI: 10.4321/ S0004-05922014000300017.

NERES, M. A.; NATH, C. D.; SUNAHARA, S. M. M. Cenário da produção e comercialização de feno e présecado no Brasil. In: SIMPÓSIO SOBRE PRODUÇÃO E UTILIZAÇÃO DE FORRAGENS CONSERVADAS, 6., 2017, Maringá. Anais... Maringá: Universidade Estadual de Maringá, 2017. p. 141-169.

PASQUALOTTO, M.; NERES, M. A.; GUIMARÃES, V. F.; KLEIN, J.; INAGAKI, A. M.; DUCATI, C. Gas exchanges and dehydration in different intensities of conditioning in tifton 85 bermudagrass: nutritional value during hay storage. Asian-Australasian Journal of Animal Sciences, Seoul, v. 28, n. 6, p. 807-815, 2015. DOI: 10.5713/ajas.14.0826.

RAYMOND, F.; SHEPPERON, G.; WALTHAM, R. Forage conservation and feeding. $3^{\text {th }}$ ed. Ipswich: Farming Press, 1978. 188 p.

RIBEIRO, K. G.; PEREIRA, O. G.; VALADARES FILHO, S. C.; GARCIA, R.; CABRAL, L. S. Caracterização das frações que constituem as proteínas e os carboidratos, e respectivas taxas de digestão, do feno de capim Tifton 85 de diferentes idades de rebrota. Revista Brasileira de Zootecnia, Viçosa, MG, v. 30, n. 2, p. 589595, 2001. DOI: 10.1590/S1516-35982001000200039.

ROBERTSON, J. B.; VAN SOEST, P. J. The detergent system of analysis and its application to human foods. In: JAMES, W. P. T.; THEANDER, O. The analysis of dietary fiber in food. New York: Marcel Dekker, 1981. p. $123-158$.

ROTZ, C. A.; MUCK, R. E. Changes in forage quality during harvest and storage. In: FAHEY, G. C. Forage quality, evaluation, and utilization. Madison: American Society Agronomy, 1994. p. 828-868. 
TAFFAREL, L. E.; MESQUITA, E. E.; CASTAGNARA, D. D.; OLIVEIRA, P. S. R.; OLIVEIRA, N. T. E.; GALBEIRO, S.; COSTA, P. B. Produção de matéria seca e valor nutritivo do feno do tifton 85 adubado com nitrogênio e colhido com 35 dias. Revista Brasileira de Saúde e Produção Animal, Salvador, v. 15, n. 3, p. 544560, 2014. DOI: 10.1590/S1519-99402014000300003.

TILLEY, J. M. A.; TERRY, R. A. A two-stage technique for digestion of forage crops. Grass and Forage Science, Nantwich, v. 18, n. 2, p. 104-111, 1963. DOI: 10.1111/ j.1365-2494.1963.tb00335.x.

TURNER, J. E.; COBLENTZ, W. K.; SCARBROUGH, D. A.; COFFEY, K. P.; KELLOGG, D. W.; MCBETH, L. J.; HEIN, R. T. Changes in nutritive value of bermudagrass hay during storage. Agronomy Journal, Madison, v. 22, n. 94, p. 109-117, 2002. DOI: 10.2134/agronj2002.0109.

VAN SOEST, P. J. Nutritional ecology of the ruminant. $2^{\text {th }}$ ed. New York: Cornell University Press, 1994. 456 p.
VAN SOEST, P. J.; ROBERTSON, J. B.; LEWIS, B. A. Methods for dietary fiber; neutral detergent fiber; and nonstarch polysaccharides in relation to animal nutrition. Journal of Animal Science, Champaign, v. 74, n. 10, p. 35-83, 1991. DOI: 10.3168/jds.S0022-0302(91)78551-2.

WELZ, B.; SPERLING, M. Atomic absorption spectrometry. $3^{\text {th }}$ ed. Weinheim, New York: Wiley - VCH, 1999. $941 \mathrm{p}$.

WUNSCH, C.; BARCELLOS, J. O. J.; PRATES, E. R.; COSTA, E. C.; MONTANHOLI, Y. R. Avaliação das alterações bromatológicas do feno de campo nativo durante o armazenamento. Pesquisa Agropecuária Gaúcha, Porto Alegre, v.13, n. 1-2, p.131-135, 2007.

YANG, J. H.; BRODERICK, G. A.; KOEGEL, R. G. Effect of heat treating alfalfa hay on chemical composition and ruminal in vitro protein degradation. Journal Dairy Science, Champaign, v. 76, n. 1, p. 154-164, 1993. DOI: 10.3168/jds.S0022-0302(93)77334-8. 